\title{
Civilisations
}

Revue internationale d'anthropologie et de sciences

humaines

$62 \mid 2013$

Identité, culture et intimité

\section{Speaking With and About Chinese}

Language Attitudes, Ethnic Stereotypes and Discourse Strategies in Interethnic Communication on the Russian-Chinese Border

\section{Kapitolina Fedorova}

\section{OpenEdition}

\section{Journals}

Electronic version

URL: https://journals.openedition.org/civilisations/3334

DOI: 10.4000/civilisations.3334

ISSN: 2032-0442

\section{Publisher}

Institut de sociologie de l'Université Libre de Bruxelles

\section{Printed version}

Date of publication: 31 December 2013

Number of pages: 71-90

ISBN: 2-87263-042-2

ISSN: 0009-8140

Electronic reference

Kapitolina Fedorova, "Speaking With and About Chinese", Civilisations [Online], 62 | 2013, Online since 31 décembre 2016, connection on 28 juin 2022. URL: http://journals.openedition.org/civilisations/ 3334 ; DOI: https://doi.org/10.4000/civilisations.3334 


\title{
Speaking With and About Chinese
}

\author{
Language Attitudes, Ethnic Stereotypes and Discourse Strategies \\ in Interethnic Communication on the Russian-Chinese Border ${ }^{1}$
}

\author{
Kapitolina FEDOROVA
}

\begin{abstract}
Ethnic, social and linguistic stereotypes play crucial role in interethnic communication, influencing people's perceptions and communicative strategies and shaping the way they construct images of others and themselves. Border areas where interethnic contacts constitute a necessary part of everyday reality provide researchers with an opportunity to study this process in details. The article deals with the situation on the Russian-Chinese border, the area with a long history of intensive economic, cultural and language contacts between several ethnic groups. Linguistic strategies employed by native speakers of Russian in actual interpersonal communication with Chinese speakers are studied as well as their "symbolic communication" - discourse practices of discussing and constructing images of Chinese in in-group conversations and interviews. The research is based on the field data gathered by the author in 2008-2010 in the Zabaikalskii territory of Russia and the Chinese city of Manzhouli (Autonomous region Inner Mongolia). The study combines linguistic and anthropological approaches.
\end{abstract}

Keywords: interethnic communication, border studies, foreigner talk, language attitudes, ethnic stereotypes.

Résumé : Les stéréotypes ethniques, sociaux et linguistiques jouent un rôle crucial dans la communication interethnique, en influençant les représentations et les stratégies communicatives, et en construisant des images des autres et de soi. Les zones frontalières, où les contacts interethniques font partie de la réalité quotidienne, offrent aux chercheurs une opportunité d'étudier ce processus en détails. L'article est consacré à la situation à la frontière russo-chinoise: la région avec une longue histoire de relations économiques, culturelles et linguistiques intenses entre plusieurs groupes ethniques. L'analyse porte sur les stratégies linguistiques utilisées par les locuteurs russophones dans leurs interactions avec les locuteurs chinois, ainsi que sur la " communication symbolique » - les pratiques discursives de la négociation et de la construction des images des Chinois dans les conversations en groupe et dans des entretiens. L'enquête est basée sur les données de terrain recueillies par l'auteur en 2008-2010 dans le kraï de Transbaïkalie en Russie, ainsi que dans la ville de Manzhouli en Chine (région autonome de Mongolie-Intérieure). La recherche est au croisement des approches linguistique et anthropologique.

Mots-clés : communication interethnique, études des frontières, foreigner talk, attitudes linguistiques, stéréotypes ethniques.

1 The article was written due to the support provided by the Asia-Pacific Research Centre, Hanyang University, Republic of Korea. 


\section{Introduction}

Interethnic communication, i.e. communication between persons of different ethnic and linguistic origin, makes people to deal with "otherness". In a sense it is true for any communication - we need others to converse with, and speech processes are inherently dialogical. But in the case of interethnic communication participants have a possibility to employ an additional dimension of this otherness and view themselves and their interlocutors in light of the respective ethnicity and ethnic identity, as representatives of different ethnic groups. Their words, deeds and reactions can be interpreted not as a part of individual behaviour but rather as typical for the group they belong to. Ethnic, social and linguistic stereotypes serve as convenient methods of constructing perceptions and can influence people's everyday interactions with others in a serious way. ${ }^{2}$

Linguistic issues are crucially important in the process of interethnic contacts. The choice of language of communication and particular features of language variants used in the dialogues between contacting groups reveal certain stereotypical patterns of speech behaviour. Linguistic strategies used by native speakers of a given language when communicating with non-native speakers usually are described as a part of this language's foreigner talk register, i.e. a conventional variety of simplified speech which is regarded by the speakers as appropriate for use with non-native speakers (Ferguson 1981). Studies on many European languages show that, when talking to foreigners, native speakers try to simplify their utterances in order to make them easier to perceive and understand. Various means of grammar simplification and sense clarification are employed, some of which are universal and others are unique to a particular language. Universal means include slower and louder speech, frequent repetitions, and grammar simplification (Ferguson, DeBose 1977; Meisel 1977; Hatch 1983). Another important aspect of interethnic communication is speakers' attitudes towards accented and grammatically incorrect language forms used by non-native speakers and cultural conventions about foreigners and their speech. From linguists' point of view, nonnative speakers' verbal behaviour reflects their interlanguage, the linguistic system created during the second-language acquisition process (Selinker 1972). But for native speakers these language variants can be "socially loaded", and their attitudes towards someone depends on the ways he or she uses the language (Garrett 2010) - someone speaking "broken language" has poor chances to be evaluated as smart and welleducated. Different cultures vary in their tolerance to non-standard speech (Jupp et al. 1982; Nickel 1986) and could be more or less inclined to cooperate in interethnic communication and use certain features of foreigner talk, especially those demanding serious speech modifications such as ungrammatical utterances. On the other hand such extreme consequences of contacts as new pidgin languages can arise and become

2 See numerous examples in e.g.: Bremer et al. 1996; Clyne 1994; Scollon, Scollon 1995. 
specialized communicative tools to be used in the contact zones and, in their turn, give birth to new sets of language attitudes and stereotypes. ${ }^{3}$

In other words, ethnic and language stereotypes and attitudes play crucial role both in actual communication between speakers of different languages, in their everyday interaction, and in the way they discuss each other, in what we can call symbolic communication (Herman-Kinney, Reynolds 2003). Discourse strategies employed by contacting individuals are shaped by cultural conventions and images typical for them. Discourse approach - that is treating linguistic data not only structurally but as part of its usage, as immersed in context (Johnstone 2008) - give us possibility to study and compare data obtained through different methods: audio records of natural speech, observations, and interviews. The way people from contacting groups describe each other, metaphors they use and typical discourse patterns used in actual communication reflect, at least in a way, the conventionalized images of "others" constructed in the process of communication. And border areas where interethnic communication is a part of people's everyday practices provide researchers with a chance to study this process in details.

State borders can be seen as both physical and symbolic barriers, prohibiting any uncontrolled transition between neighbouring countries, they function as sites for implementing state's power (Pickering, Weber 2006). At the same time requirements of national boundaries collide with requirements of people living in the bordering areas (Horsman, Marshall 1994; Donnan, Wilson 1999), and the very fact of the existence of borders inevitably provokes various types of economic activity on adjacent territories such as small-scale trade, tourist services etc. These economic activities, in turn, make people from the bordering states communicate with each other both literally, in their everyday interaction, and symbolically, in constructing images and perceptions. Separated by the state borders, they usually see each other as totally different: they speak different languages, have different traditions and practices, and collision of these differences influences in various aspects habitual ways of living and thinking. Mutual attitudes on the border are shaped by many factors, and state policy and propaganda can play rather serious role (Wilson, Donnan 1998). Historical background is also important since similar linguistic and behavioural patterns can be discovered in different time periods as is the case with the Russian-Chinese border area which is in the focus of my article. To reveal the role played by stereotypes in interethnic communication between people from bordering territories I will analyze discourse strategies employed by Russian native speakers both in actual communication with Chinese speakers and in their discourse about Chinese. The research is based on data gathered during my field work ${ }^{4}$ in the Zabaikalskii territory of Russia and the Chinese city of Manzhouli (Autonomous region Inner Mongolia) in 2008-2010. Several methods of obtaining

3 Pidgins are contact languages created by speakers of different mutually non-understandable languages to communicate with each other in restricted social conditions. Typical pidgin languages, such as Pidgin English or Tok Pisin, emerged in colonies, plantations or in important trade zones. Non-specialists' attitudes towards pidgin languages were, and in most cases still are, rather negative: they are considered to be "grammatically incorrect" and "stupid". See: Romaine 1988; Todd 1974.

4 The field work was supported by the German Research Foundation grant "Russian-Chinese Language Contacts and Border Trade: the Past and the Present" (GZ: 436 RUS 113/960/0-1). 
data were used: observation (including participant observation); audio recording of spontaneous interaction between Russian and Chinese speakers; interviews (conducted in Russian) with Russian and Chinese speakers from different ethnic and socioprofessional groups with different levels of involvement in the interethnic contacts; gathering data on linguistic landscape; gathering data from web-sites and forums dedicated to border area and related border-crossing practices. It should be noted here that it is Russian speakers who are in the focus of my study, partly because thorough research on Chinese' attitudes towards Russians demands more profound knowledge of the Chinese language and culture, and partly because of my theoretical interest in language choice problems: whereas Chinese speakers communicating with Russian speakers use the only language variant available to them (Russian interlanguage) Russian speakers can choose from broad range of variants, and the very choice they make can tell a lot about the way they see Chinese speakers.

Another important note concerns the terms "Russians" and "Chinese" used in the article. They should by no means be understood exclusively as labels of particular ethnic groups ${ }^{5}$ or even nationalities. The "official" ethnic situation in the border region, especially in the Zabaikalskii territory where my field data was gathered, is usually described as rather heterogeneous: besides ethnic Russians and Han Chinese there are Buryats, Mongols, Manchu and many ethnic minority groups (such as Udege or Orochs). Actual ethnic identity construction is certainly more complicated and situational but what is important for the purposes of my article is the fact that Russian speakers interpret the situation in terms of ethnic labelling and disregard more subtle distinctions when confronting (through actual or symbolic communication) those whom they describe as "kitajtsy" (the Chinese). Groups are constructed through borders and differentiation (Barth 1969). "Russians" and "Chinese" therefore refer to citizens of Russian and China whose dominant language (or one of two or more dominant languages) is Russian and Chinese (i.e. one of Chinese dialects) respectively. These categories per se are super-ethnic constructions, terms in which contacting groups see each other, since the clear-cut distinction between "russkie" (Russians) and "kitajtsy" (the Chinese), "us" and "them" plays important role in people's discourse.

\section{The Russian-Chinese border area: an overview}

For centuries the area around the border between Russia and China was a place of intensive economical, cultural and linguistic contacts not only between the Russians and the Chinese; several ethnic groups (Mongolians, Koreans, Tungus, Udege and others) were involved in the process as well. Since 1727, when the treaty of Kyakhta was concluded, this small frontier town became the only place where Russian and Chinese merchants could perform trade deals (Stern 2005). Strict regulations on trade continued for 133 years (till 1860), and the situation turned out to be ideal for the emergence of a new language, the so-called "Kyakhta language", or Russian-Chinese pidgin. Later it spread along the border all the way to the Russia's Far East, and gradually became the main tool for interethnic communication in the region, with a great number of speakers

See Brubaker 2004 on critique of "groupism” approach to ethnicity. 
belonging to at least eight ethnic and linguistic groups (Belikov 1994: 297-298). ${ }^{6}$ The pidgin was documented by travellers and amateur linguists (e.g. Cherepanov 1853; Maksimov 1864) amused by this "funny language", "Chinese Russian" as they referred to it; it was also used in the fiction to depict the way the Chinese and aboriginal people of the Far East spoke Russian. The most famous examples are the books by Vladimir Arsenjev (Arsenjev 1978) "Po Ussurijskomu krayu" and "Dersu Uzala" (later made into a movie by Akira Kurosawa). For most Russian native speakers, this language was no more than just "broken Russian", a grammatically incorrect version of the "true language". It lacked social prestige and was used by Russians to communicate with underprivileged social groups - aboriginal people (Tungus, Udege), Chinese seasonal workers and street vendors. The attitudes towards both "Chinese Russian" and its speakers were condescending: it and they were not liked, but had to be tolerated. Stereotypical images of Chinese, poor, cunning and speaking bad Russian, became part of mass culture. At the same time the official discourse of so called "yellow peril" developed in public discourse spheres (Siegelbaum 1978).

The Russian-Chinese pidgin existed and developed for almost two centuries as the language of interethnic communication. But in the late 1930s with repression in the Soviet Union and a falling-off in relations with China the border between two countries was closed, the Chinese were deported (Perekhvalskaya 2007), and any communication across the border became impossible. Gradually, a strong Russification policy has done its part, and most aboriginal people shifted from "broken" to normative Russian. As a result, the Russian-Chinese pidgin passed out of use and soon was forgotten.

Now, after 50 years of separation, contacts resumed and became indispensible part of everyday life both for Russian and Chinese speakers in the border area. At the very end of the 1980s, serious changes in the Soviet Union resulted in the loosening of border regulations. It became possible for the people from the Russian-Chinese border area (Amur and Chita regions, the Khabarovsk Territory, the Jewish Autonomous Region, and Primorye) to cross the border without pre-arranged visas, instead obtaining entry permits at the check-points themselves. At the beginning of the 1990s, cross-border trade became the main source of income for many Russians, and cheap Chinese goods invaded the region. The opening of the Russian market for the Chinese stimulated substantial migration between the two countries, and transformed Chinese settlements near the border (e.g., Heihe and Manzhouli). In less than ten years, small frontier posts changed into cities populated by hundreds of thousands of people. The urban landscape of the cities and towns on the Russian side of the border underwent serious changes as well resembling in a sense Chinatowns in many European and American cities (Dyatlov 2008). Chinese markets became an indispensable part of these cities' everyday life. Therefore since Perestroika unofficial transborder trade (so called "shuttle trade") has been developing very fast affecting life-styles and everyday activities of most people from the border region. Because of strict custom regulations on the Russian side of the border traders have to hire different people (so called "kemely" - from the English word "camel") to transport goods.

6 There are different theoretical approaches to these variants among linguists. Some of them consider the Kyakhta language and the Far East pidgin to be the same language; others believe them to be separate (see Perekhvalskaya 2008). 
That's why many Russians professionally not related with trade business - such as teachers, students or even university professors - have some experience of shuttle trade: they go to China from time to time to earn some money on the side and enjoy short vacations (Fedorova 2011b). The prices on the Chinese side of the border are significantly lower, and those people can allow themselves some things they can not afford at home like shopping, eating out or going to spa. For most Russians therefore borderland China is a destination for shopping tourism, they do not come to work and spend only several days there. The opposite situation is true for the Chinese coming to Russia - they are mostly labour migrants.

According to official statistics, in 2006 migrants from China constituted almost $23 \%$ of overall number of labour migrants working in Russia thus being the biggest immigrant group. At the same time only small number of them was registered as moved to Russia permanently. Sociological researches confirm the fact that Chinese immigration to Russia has seasonal character and most migrants come to work only for limited periods of time and usually do not plan to stay there (Larin 2001; Gelbras 2004; Portyakov 2006). In average, Chinese workers spend from 6 to 10 months in Russia and return for the rest of the year to their home places where they can use the money earned during their stay abroad to upgrade their living conditions. These workers are mostly employed in construction business, agriculture and small trade enterprises. Their educational level is usually low and they often originate from rather poor rural areas of northern Chinese provinces. As a rule they can speak no or very little Russian. Smaller part of migrants (around 10-15\%) have businesses of their own and live in Russia more or less permanently and usually with their family but they tend to keep close contacts with China at the same time. Members of this group have higher educational level and possess at least some knowledge of Russian so they can serve as mediators between native Russian speakers and Chinese workers employed by them. It should be underlined that this kind of social distribution of migrants is typical mostly for border regions of Eastern Siberia and the Far East whereas in Moscow and other cities in the European part of the country Chinese businessmen and students prevail over manual workers. Having in mind these social conditions of interethnic contacts we can now turn to discourse practices of the border areas.

\section{Speaking with Chinese: modes of interethnic interaction}

To understand the situation with interethnic communication in the border area it is important to consider the fact that the social distribution of communication patterns on both sides of the border is asymmetrical: in both cases it is Chinese people who make efforts to learn Russian and not vice verse; as my field data shows very few native speakers of Russian, mostly young people, try to learn Chinese as a part of their professional training. Even women married to Chinese men do not usually speak Chinese at all or only know several words and phrases, and if they try to learn the language they apt for professional instructions and not for the help of their spouses and Chinese relatives. The Russian language therefore serves as a medium of interethnic communication; speaking Russian is believed by its speakers to be sufficient for any communicative purpose and no particular value is attributed to Chinese as a language 
for everyday interactions. In their contacts with Chinese native speakers of Russian can rely upon their interlocutors' ability to speak their language.

At the same time the Russian language as spoken by the Chinese is not an "ordinary" Russian. Very few Chinese immigrants, especially those employed in manual labour, get any formal language instruction; the overwhelming majority of them learn Russian during their communication with Russians in everyday situations or pick up some words from their linguistically more competent fellow countrymen. ${ }^{7}$ The resulting language variant has many phonetic, lexical and grammar features differing this ethnolect ${ }^{8}$ from standard Russian. Chinese' "broken" Russian is also used in written communication. Signs, advertisements, instructions on goods packing etc. demonstrate numerous mistakes in Russian grammar and spelling. Ungrammatical forms and phonetic transformations typical for "Chinese Russian" are perceived as erroneous and extremely funny by native speakers of Russian, and in native to native communication the same features are widely used for imitating and parodying the way "silly Chinese" butcher the Russian language. Chinese speakers therefore despite the fact that it is they who make efforts to ensure the communication is more or less successful expose themselves to negative language stereotypes: their speech is mocked and they are treated as linguistically incompetent.

On the other hand, using Russian and not Chinese for interethnic communication does not necessary mean that native speakers of Russian do not adjust their verbal behaviour to the contact situation in some ways. In fact, in their communication with Chinese two main different modes, or registers, can be discovered which can be respectively labelled as "weak" and "strong" forms of foreigner talk. The first one ("the weak form") is used by those Russians who do not have close contacts with Chinese and interact with them from time to time only at the markets or on the streets. This type of language behaviour differs only slightly from "ordinary" colloquial Russian. There are several foreigner talk features like repetitions, paraphrases, slower speech tempo and increased loudness but usually they are employed only when communicative breakdowns occur:

\section{R[ussian]: A eta shuba skol'ko? (How much is this fur-coat?) \\ $\mathrm{Ch}[$ inese]: $A$ ? (What?) \\ R: [louder] Shuba eta, skol'ko stoit? (This fur-coat, how much does it cost?)}

Chita, records at Chinese market, 2008)

Some lexical items however are used in this register which are unknown outside the region and originate either from professional slang or from Chinese ethnolect of Russian. Among most popular words are: "kapitana" (chief; from Russian "kapitan" captain); "druga" (friend; from Russian "drug" - friend); "kunya" (girl; from Chinese

7 The distinction between instructed language learning and language acquisition in natural linguistic environment is crucial for second language acquisition studies. See e.g.: Krashen 1981; Andersen 1983.

8 I.e. language variant typical for a particular ethnic group. This variant can stabilize over time and begin to be used not as a single linguistic resource of a given group but rather as a part of its linguistic repertoire, a specific register which can be used by the second or third generation of migrants to mark their ethnic identity. See e.g.: Cornips 2008. 
"gūniang" - girl); "super-minimum" (the lowest price; the combination of the Russified forms of Latin words "super" and "minimum"); and "kemel" already mentioned in the previous section of the article. These words are used both by Russian and Chinese speakers and should be considered as a part of a compromise linguistic strategy which is typical for interethnic communication. At the same time it should be noted that language behaviour patterns witnessed in border regions differ in many ways from those of Russian native speakers communicating with Westerners. As my previous study in St. Petersburg showed (Fedorova 2006) in their contacts with foreigners native speakers of Russian prefer to use hypercorrect language variant very different from colloquial speech. Compare the following examples produced by the same person (middle-aged Russian woman) during one table-talk:

(1) R: [addressing other R] Kurochku budesh?

(2) R: [addressing her American friend] Ty budesh kuritsu?

(St. Petersburg, records, 2001)

The meaning of both sentences is the same: "Will you eat chicken?" But in the first case (native speaker to native speaker communication) diminutive form ("kurochka" instead of "kuritsa") and inverted word order along with omission of personal pronoun "ty" (you) is used which is natural for colloquial speech. When addressing the same question to a foreigner the speaker employs standard grammar and avoids diminutives. As a result the sentence is technically correct but sounds slightly unnatural in the context of table-talk - foreigners get "pure" Russian not "spoilt" by colloquial "imperfections". But, as comparison of data from St. Petersburg and the Zabaikalskii territory shows, such linguistic strategies are not employed in communication with Chinese speakers in the border area, colloquial speech forms are used instead. ${ }^{9}$ Chinese people we can conclude are not considered by Russians as suitable to be addressed with "high" or "correct" speech variety, lack of social and linguistic prestige in their speech make them play subordinate social role. Chinese are not treated as "dear guests" like Westerners (see Fedorova, Gavrilova 2010) but rather as inferiors to their Russian interlocutors.

This suggestion is confirmed by native speakers' choice of form of address regardless their age and sometimes even social status Chinese are addressed by singular form of personal pronoun " $t y$ " instead of polite plural form " $V y$ " ${ }^{10}$ Compare:

(1) R: [addressing Russian salesman] Vy ne pokazhete etot [telefon], Nokia?

(Will you show this [mobile phone], Nokia?)

(2) R: [addressing Chinese salesman] Kurtku pokazhi von tu, beluyu. (Show me that jacket, the white one)

(Chita, records at the Chinese market, 2009)

9 This fact can not be explained by regional differences between Western and Eastern Russia. The same informants in Chita who addressed Chinese in colloquial Russian, in their communication with my German colleague Dieter Stern demonstrated the same hypercorrect strategies I discovered in St. Petersburg data.

10 On distinguishing between " $t y$ " and " $V y$ " and cultural norms of these pronouns usage in Standard Russian see e.g.: Friedrich 1972. 
Chinese speakers therefore linguistically are treated differently both from Westerners and fellow Russian citizens. What is even more interesting, close observation of contacts between Chinese and those Russian speakers who are deeply involved in interethnic communication on everyday basis (employers, tourist agents, spouses in mixed marriages etc.) reveal another type of language behaviour - the use of "strong" or "classic form" of foreigner talk register, so called broken language (never used in communication with Westerners). In their attempt to make their speech easier to perceive for non-native speakers informants employ ungrammatical utterances and semantic simplifications. Typical features of this register are following: 1) No declination is used: nouns, adjectives and pronouns are in nominative; 2) No conjugation is used: imperative serves as a basic verb form, modal verbs are used in first singular form; 3) Nouns are used as adjectives; 4) Subject - Object - Verb word order prevails; 5) Numerous semantic simplifications are employed, e.g. "bumaga" (paper) for any document. These features can be illustrated by following examples:

Ya Oksana pozvoni. (I called Oksana)

(Chita, records at the Chinese market, 2008)

Should be: Ya pozvonila Oksane.

Esche gost'budet. Chita-gost'. (Another guest will come. A guest from Chita)

(Mogojtuj, records at the brick factory, 2009)

Should be: Eto chitinskaya firma.

[Telefon] ne mogu, antenna ne rabotaj, menyaj. ([This mobile] can't work, the antenna doesn't work, change it)

(Chita, records at the Chinese market, 2008)

Should be: ne mozhet, antenna ne rabotaet, menyaj.

Ya ty bumaga pishi. (I'll write an official certificate for you) (Aginskoe, records at the furniture factory, 2009)

Should be: Ya napishu tebe spravku.

Curiously all these linguistic features are very similar to those of the RussianChinese pidgin which was used in the same region one hundred years ago. ${ }^{11}$ But what is more important for the topic of stereotypes usage is the fact that in this type of language behaviour again we can see that Chinese speakers are not treated as equals. Their limited command of Russian makes their Russian interlocutors turn to ungrammatical speech rather than simple but grammatically correct utterances which are used with other foreigners. In other words there is a strong tendency to very asymmetrical organization of interaction: one contacting part (Russian speakers) see themselves as superior to the other part (Chinese) and use different "talking down" strategies either refusing to adjust to contact situation (no or very little foreigner talk features) or employing ungrammatical utterances (strong foreigner talk features).

It is also important to mention that all informants who use the second strategy express rather negative feelings towards this "broken language" and are reluctant to

11 See examples in Fedorova 2011a. 
admit the fact they themselves speak that way. As a whole, speakers of Russian are strongly oriented towards standard language, and usually are embarrassed to admit they can use a "broken language". In most cases, informants try to avoid speaking this way in the presence of the witness, especially a researcher, who is treated as an educated and "cultured" person (and that makes obtaining data really challenging). Any reference to this form of language is accompanied by explanations like the following:

$\mathrm{Nu}$, my tut s nimi sami uzhe russkij yazyk zabyli. Oni zhe ne ponimayut inache, vot i prikhoditsya yazyk lomat'. Uzhas, konechno

(Well, here with them we forgot Russian ourselves. They don't understand otherwise, so we have to break the language. It's terrible, of course)

(Aginskoe, interview with a woman supervising Chinese workers at the furniture factory, 2008).

In other words, usual justification for using foreigner talk is: “They won't understand otherwise" but even being unavoidable this type of speech is shameful and disgusting in the eyes of Russian speakers. Linguistic attitudes therefore both towards the way Chinese speak Russian and the way they make Russians speak it are strongly negative in the border region which again corresponds with attitudes towards the RussianChinese pidgin and to pidgin languages in general.

\section{Speaking about Chinese: discourse strategies and ethnic stereotypes}

Twenty years of interethnic contacts and socio-economic transformations in the border region created not only new modes of actual communication but influenced the way Russian speakers employ images of the Chinese in their in-group discourses. China and its citizens play important role in everyday life of Russian border regions. Daily interactions with Chinese both in Russia and in the Chinese border cities are so common for most people of the area that these matters are mentioned all the time in conversations with their friends and family members. People relate their experience, discuss problems, tell jokes, and Chinese present an indispensible part of this everyday discourse. Comparisons between Russia and China, Russian and Chinese are very frequent; it is not surprising that they provoke reflections on such matters as ethnic identities and differences in habits and practices. Of course, these reflections become more elaborated in interviews centred on Chinese and their role in the region but they are not uncommon in "natural" conversations as my interactions with local people who knew nothing about my research show. Some of them, especially taxi drivers, brought up the topic of the Chinese themselves just to start a conversation with a stranger.

Citizens of Russian regions bordering with China, we can conclude, speak a lot about their Chinese neighbours, and, it should be said, mostly in negative, and sometimes shockingly rude, terms. Lamentations about "bad Chinese" are common both in in-group conversations and in interviews with a researcher. These lamentations and stories used to illustrate them are surprisingly similar in discourses of very different people; in a broad sense these texts follow the same structure and are shaped by several unquestioned ideas and clichés about Chinese and their presence in Russia. On the base of these repeated texts a sort of border text, or prototext, or border myth can be 
reconstructed. Of course, as any myth this one does not necessary reflect the reality correctly. In this article I will not try to judge if this or that stereotype has anything to do with some real facts but will analyse them as a part of the constructed social reality in Berger \& Luckmann's sense (Berger, Luckmann 1966). It should be noted as well that unlike the situation in Western countries (Van Dijk 2002) political correctness and ban against overt racist discourse is not fully established in Russia. There is no need to look for unconscious racists "slips" in media discourse (see e.g. Haskell 2009): ethnic prejudices and nationalistic ideas are rather often expressed openly in mass media, educational materials, and by scientists and public figures (see Voronkov et al. 2002; Voronkov et al. 2008) and in everyday discourse they are, unfortunately, absolutely common and unproblematic. High level of xenophobia in modern Russia is confirmed by numerous sociological surveys (Gudkov 2007).

The border text reproduced by anyone living in the area describes three time periods of the border zone - before Perestroika, the 1990s, and modern situation - and has all features of mythological perception: time before time, golden age and constant decline. According to this myth, before Perestroika the region which served as a base for many military units was rather rich and quiet place with relatively high standards of living. In fact not many people have actual memories of this period since there are many newcomers in the region. After opening of the border Russians started to visit Chinese border cities and buy Chinese goods. This time - the first half of the 1990s - provokes ambivalent feelings in informants. For most of them rapid economic changes in Russia meant deprivation and miserable existence but those who started their business with China at the time see the same period as the most successful in their career since differences in prices in Russia and China and lack of border regulations gave them opportunity to get huge profits:

\section{Togda ved'skol'ko khochesh vozit'mozhno bylo, khot'kazhdyj den'. Za polgoda na kvartiru mozhno bylo zarabotat'!}

(That time you could bring as many goods as you wanted, even every day. In half a year one could get enough money to buy an apartment!)

(Novoorlovsk, interview with a saleswoman at the market, 2009).

But despite different attitudes towards the 1990s everyone agrees that that "first" Chinese who flooded the area at the time were very different from today's ones: there is common belief that Chinese changed drastically during the years of contacts with Russians. Once they were dirty, uneducated and as a whole "uncivilized" but also unspoiled by civilization - honest, respectful and "knew their place". As one of my informants - female student from Chita university - put it:

Oni togda sovsem dikie byli, eli odin ris, odevalis' $v$ takie shtany $i$ rubakhi korichnevye, vse, i muzchiny, i zhenschiny, odinakovo. I ochen'vezhlivye, russkie dlya nikh kak bogi byli. Teper'-to oni osmeleli, naglye stali, ran'she boyalis'.

(They were absolutely savage at the time, they ate only rice and wore such brown pants and shirts, all, men and women alike. And they were very polite, Russians were gods for them. Now, they grew bolder, became cheeky, but before they had fear).

(Train Chita-Zabaikalsk, interview, 2008) 
Most popular explanations of these changes in Chinese' behaviour relate them with "bad influence" from Russians who taught Chinese to drink alcohol, swear in Russian, cheat, fight and be rude - to quote my other informant, middle-aged businesswoman from Zabaikalsk: "My sami ikh isportili" (We spoiled them ourselves) (Zabaikalsk, interview, 2010). Interestingly this justifying type of discourse ("Chinese are not guilty, we are spoiling them"), according to my interviews, is more typical for women, especially middle-aged, whereas men demonstrate more negative attitudes towards Chinese and overtly express their prejudices. Another important factor relevant for ethnic attitudes is the level of involvement in interethnic communication. The same way as actual speech behaviour of those informants who are deeply involved in contacts with Chinese differs from speech strategies of those for whom Chinese are nothing but strangers (see the previous section of this article) people with a strong interethnic experience of their own sympathize more with Chinese and refrain from overt negative remarks. The same people tend to express more critical attitudes towards fellow Russians and their drinking habits and lack of enterprise. Quite often comparisons between Russian and Chinese men (which are not to the benefit of the former) are employed for justification of mixed marriages:

A za kogo im tut zamuzh-to idti? Vse muzhiki kto pjot, rabotat' ne khotyat. A za kitajtsem spokojnee, oni-to ne pjut. Esli normal'nogo muzhika ne najti, khot'za kitajtsa vyjdesh.

[And whom are they supposed to marry? All [Russian] men, some of them drink, they do not want to work. And with Chinese men one can be more safe, them, they do not drink. If you can't find a normal man you are ready to marry anyone, even the Chinese].

(Zabaikalsk, interview with a woman whose daughter is married to a Chinese man, 2008)

At the same time the very fact that such justifications are needed reveals people's uncertainty of "normality" of such marriages.

Regarding the modern situation common opinion of the border dwellers is very pessimistic: border regulations and corruption became so strong that small trans-border business is doomed; China is becoming more and more expensive so soon there will be no sense to go there; and Chinese grew more and more hostile to Russians. In support of the latest view several "horror" stories are told, and at least some of them even if treated by informants as real can be regarded as depersonalized folklore texts (with typical beginning "Odna zhenschina poekhala v Manzhuriyu..." (A woman went to Manzhouli...)) repeated by everyone. Thus, one such story - about a woman killed by Chinese shopkeepers when she tried to make them return her money she had paid for some fake fur-coat - was told me twice in Chita, once in Aginskoe and once in Zabaikalsk by four different people not knowing each other.

The border discourse therefore describe relations with the Chinese, on the one hand, as a part of the region's economic history and, on the other hand, as a collision between 
two very different cultures one of which (Russian) is seen as dominant and influential whereas the other (Chinese) is inferior and receptive.

This notion can be supported by analysis of metaphors used by Russian speakers to describe the Chinese. Undoubtedly metaphors constitute an important part of any discourse and reveal basic assumptions, conceptual system typical for speakers of a particular language (Lakoff, Johnson 1980). Of course these assumptions should not be interpreted as stable systems of thought since they tend to be, as discourses themselves, fluent and immersed in broad context. The very same person, depending on the situation in which the conversation occurs, can describe another person, or group of people, in many different ways. At the same time in interethnic contacts analysis of metaphors referred to "others" can provide a researcher with more subtle analytical instrument than direct questions about attitudes since metaphors are based on some features which are considered to be similar in different and sometimes very distant object, and these similar features are important for understanding the way language speakers can see and perceive the objects in question. In this respect metaphors referred to the Chinese by Russian native speakers of the border region are rather interesting. They are based on such qualities as "physically small", "numerous" and "extremely adaptive": the Chinese are routinely compared to small animals and insects like mice, rats, ground squirrels, ants and cockroaches:

[about Chinese migrants in Zabaikalsk who run away so not to be interrogated by migratory police]

Oni i razbegutsya $v$ step' [...] Sidyat, boyatsya. Mashina edet - pryachutsya. Pryamo kak krysy. [...] tam pod zemlej khody, tak oni v etikh norakh pryachutsa, susliki...

(They run away to steppe [...]. They sit there, in fear. If a car goes, they hide away. Just like rats. [...] there are passages under ground there and they hide away in them, ground squirrels...).

(Zabaikalsk, conversation with a taxi driver, 2009)

Na strojke rabotayut - begayut kak muravji, tol'ko kaski raznotsvetnye mel'kayut. (When they work at the building site they run around like ants. Just their colored helmets flit about).

(Zabaikalsk, interview with an elderly man, 2009)

[about deportations of Chinese with expired visas]

Voobsche, pravil'no, konechno, a to oni razbredayutsya, po vsej Rossii raspolzayutsya.

(As a whole it is right of course, otherwise they wander off, crawl around the whole Russia).

(Zabaikalsk, interview with a middle-aged man, 2009)

In the last example there are no direct mentions of animals or insects but the use of the verb "raspolzat'sya" (to crawl) associated with insects uncover the metaphorical meaning intended by the speaker. Chinese people therefore in the eyes of their Russian neighbours are small, look alike and can live and work in any conditions. These metaphors can be used unconsciously even by those who overtly declare positive feelings towards Chinese appraising their enterprise, diligence and modesty. But in most cases such well-disposed persons who are usually closely involved in contacts with Chinese tend to resort to another metaphorical row and compare Chinese not with 
animals but with children both directly and indirectly, through using diminutives with regard to them:

[about problems in supervising Chinese employees]

Chto s nimi khorosho - oni kak deti, vse tebe rasskazyvayut, vsem delyatsya.

(What makes it easier with them - they are like children, they tell you everything, share everything).

(Aginskoe, interview with a woman supervising Chinese workers at the furniture factory, 2009)

[about young Chinese man who is afraid to be deported]

Stoit, glazyonki svoi vytaraschil, lepechet: "Ne nada, ne nada!"

(He stands, stares with his eyes [with diminutive suffix], babbles: "Don't, don't!').

(Makkaveevo, conversation with a middle-aged woman, 2009)

Certainly differences between "positive" (children) and "negative" (insects, vermin etc.) metaphorical rows are interesting but of no less importance is the fact that these two basic metaphors ("the Chinese are animals" and "the Chinese are children") can be united by the same basic assumption: the Chinese are not (mature) human beings, not equals, "not like us". Their inferiority in the eyes of Russians makes them subordinate in actual communication (as we saw in the previous section) and is reflected in metaphorical images of Chinese created in discourse.

Another important aspect of speaking about the Chinese in the border area is pronouns usage in this discourse. First, the Chinese are usually referred as "oni" (they) or sometimes "eti" (these) often without actual naming even at the first mention:

Researcher: A rynok kak, rabotaet?

(And what about the market, does it work?)

Informant: $\mathrm{Nu}$, snachala eti vse zatailis', no bystro vsyo, nanyali russkikh devok-prodavschits i snova torguyut.

(Well, first [after the new law forbidding foreigners to sell on Russian markets was administered] these all were in hiding, but soon it was over, they hired Russian girls as sellers and sell again).

(Zabaikalsk, interview with a middle-aged male official, 2010)

Furthermore these "oni" (they) are constantly opposed and contrasted to "my" (we), the cultural differences between contacting ethnic groups are reflected upon and discussed as a part of "them against us" discourse:

My tak kak oni rabotat'ne smozhem, srazu sdokhnem.

(We won't be able to work as they do, we'll kick the bucket at once).

(Novoorlovsk, conversation with a middle school teacher, 2010)

Oni svoyu edu edyat, i nichego, a my dva dnya v Kitae $i$ khochetsya uzhe normal'noj chelovecheskoj edy. 
(They eat their food and it's OK for them but we after two days in China, we want some normal human food). ${ }^{12}$

(Zabaikalsk, interview with a tourist agent, 2009)

This type of pronoun usage is crucial for alienation strategies typical for war rhetoric (e.g. Oddo 2011) or polarization of competing social groups (e.g. Zhang 2002). The differences are stressed and any similarities are ignored, positive qualities are attributed to "us" and negative to "them". Even "good" traits attributed by ethnic stereotype to the Chinese, such as their famous diligence, are perceived as a display of their inhuman nature: "Normal'nyj chelovek tak vkalyvat' ne budet" (No sane person will work that hard $)^{13}$ (Chita, interview with a female student, 2008). The Chinese therefore are constructed as an ethnic group totally different from Russians, absolute aliens. Ethnic stereotypes and groups' contraposition influence perceptions of the real Chinese people involved in interethnic communication. Personal relations even between spouses in mixed marriages can be expressed and evaluated through the "us versus them" pattern:

Konechno, my sovsem raznye, kul'tury u nas, kak my dumaem, ya chto khochu skazat', inogda on [informant's Chinese husband] prosto ne ponimaet, chego ya obizhayus'. Tyazhelo, konechno, prikhoditsya prisposablivat'sya kak-to... Oni sovsem po-drugomu dumayut.

(Of course, we are so different, our cultures, the way we think, I mean, sometimes he just can't understand why I take offence. It is difficult of course, one has to adjust in a way... They do not think like us).

(Aginskoe, interview with a middle-aged woman married to a Chinese man, 2009)

As a result of opposing "us" and "them" "my" (we) gets new meaning as well. In contrast it begins to expand and cover not just local people but Russians, Russian citizens or even Europeans, people of Western culture. Confronted with "aliens" from China such important oppositions as Siberia vs. European Russia, Russians vs. Buryats, and Russians vs. foreigners become neutralized. Those people who are usually excluded from " $m y$ " category (e.g. Buryats for ethnic Russians) become part of "us". This expanded use of personal pronouns and constructing of broad groups is more typical for media discourse than for everyday communication (O'Keefe 2006) but one can assume that interethnic contacts promote usage of the same strategy for constructing images and identities for oneself as well as for others.

\section{Conclusion}

Summing up, our analysis of interethnic communication in the Russian-Chinese border area demonstrates fundamental asymmetry between two contacting groups:

12 Here we can see another demonstration of treating (if subconscious) the Chinese as non-humans: their food is not "normal human food". There are many examples of this kind when words like "chelovecheskij" (human) or "lyudi" (people, human beings) are referred to Russians but not to the Chinese.

13 Someone working too hard can say about him- or herself: "rabotayu (or pashu, or vkalyvayu) kak kitaets" (I'm working as a Chinese) with an evident reference to the abnormality of such a situation. 
both in linguistic strategies employed in actual communication and in discourse means of constructing images Russian speakers consider themselves to play a dominant role and treat their Chinese interlocutors as their inferior. One can say that these linguistic patterns merely reflect existing distribution of social roles in the region. In a way it is true of course but language attitudes and stereotypes, in their turn, support and transmit this existing asymmetry, stabilizing the situation and providing Russian speakers with ready images of the "uneducated and uncivilized" Chinese not able to communicate in the "right" language. Symbolic power (Bourdieu 1991) therefore is attributed by Russian speakers exclusively to themselves whereas their opponents are left with improper language tool and become the target of derision.

Rigidity and strength of linguistic stereotypes in the border area can be illustrated by the following example: one of my informants, young medical doctor married to a successful Chinese businessman, who speaks fluent Russian, when I told her that there are some people who use "broken Russian" to communicate with Chinese exclaimed in astonishment:

\section{Kak eto? Ne kitajtsy prisposablivayutsya k russkim, a russkie nachinayut govorit' po-kitajski?}

(How can it be? Not the Chinese adjust to Russians but Russians start to speak in Chinese?).

(Chita, conversation, 2009)

Evidently at least two basic assumptions can be extracted from this exclamation: first, it is the Chinese who should accommodate and not Russians; second, "broken Russian" means "Chinese", i.e. to speak Chinese is not to speak Mandarin but to break the rules of the Russian language. Chinese are so closely associated with this stigmatized and non-prestigious language variant that they are evaluated and treated as linguistically and, consequently, culturally and intellectually deprived. In this sense language as a "machine" that "generates, and as a result constitutes, the social world" (Jorgensen, Phillips 2002: 9) makes it possible for contacting sides to interpret their otherness as hierarchical relations rather than partner ones and impedes interpersonal interethnic communication. Whether this set of attitudes and linguistic stereotypes is a new phenomenon in the border area or, considering the long history of contacts and existence of a pidgin language in the past, it is possible to speak about some cultural, or collective, memory ${ }^{14}$ influencing actual social relations is a question for further research. At least some features, such as typical grammar changes and the usage of metaphors and pronouns referred to Chinese speakers, which can be discovered in written sources on the situation in the Russian-Chinese border area in the past confirm the latter idea.

14 These terms usually are associated with Jan Assmann's and Maurice Halbwachs's work respectively (see Assmann 1992; Halbwachs 1992). In case of my study Yurii Lotman's semiotic approach which treats cultural memory as a transpersonal method of transferring texts can be seen to be more appropriate (Lotman 1992: 200-202). 


\section{References}

Andersen, Roger W. (ed.), 1983. Pidginization and Creolization as Language Acquisition. Rowley: Newbury House Pub.

Arsenjev, Vladimir, 1978. Po Ussurijskomu krayu; Dersu Uzala [In the Ussuri territory; Dersu Uzala]. Leningrad: Lenizdat.

Assmann, Jan, 1992. Das Kulturelle Gedächtnis: Schrift, Erinnerung und Politische Identität in frühen Hochkulturen [Cultural Memory: Writing, Memory and Political Identity in Early High Cultures]. Munich: Beck Verlag.

Barth, Fredrik, 1969. Ethnic Groups and Boundaries. The Social Organization of Culture Difference. Oslo: Universitetsforlaget.

Belikov, Vladimir, 1994. "Russko-kitajskij pidzhin" [The Russian-Chinese pidgin], in Vyacheslav Pan'kin (ed.), Kontaktologicheskij entsiklopedicheskij slovar'-spravochnik. 1, 294-298. Moscow: Az.

Berger, Peter L. \& Thomas Luckmann, 1966. The Social Construction of Reality. Garden City, New York: Anchor Books.

Bourdieu, Pierre, 1991. Language \& Symbolic Power. Cambridge, Ma: Harvard University Press.

Bremer, Katharina et al., 1996. Achieving Understanding: Discourse in Intercultural Encounters. London \& New York: Longman.

Brubaker, Rogers, 2004. Ethnicity Without Groups. Harvard University Press.

Cherepanov, Sergey, 1853. "Kyakhtinskoe kitajskoe narecie russkogo yazyka" [The Kyakhta Chinese dialect of the Russian language], Izvestiya Akademii nauk po otdeleniyu russkogo yazyka i slovesnosti, 2, pp. 230-236.

Clyne, Michael, 1994. Inter-cultural Communication at Work. Cultural Values in Discourse. Cambridge: Cambridge University Press.

Cornips, Leonie, 2008. "Losing Grammatical Gender in Dutch: The Result of Bilingual Acquisition and/or an Act of Identity?”, International Journal of Bilingualism 12, (1 \& 2): 105-124.

Donnan, Hastings \& Thomas M. Wilson, 1999. Borders: Frontiers of Identity, Nation and State. Oxford: Berg Publishers.

Diatlov, Viktor, 2008. "Rossiia: v predchuvstvii chainataunov" [Russia in presentiment of Chinatowns], Etnograficheskoe obozrenie 4: 6-16.

Fedorova, Kapitolina, 2006. "Russian Foreigner Talk: Stereotype and Reality", in Dieter Stern \& Christian Voss (eds), Marginal Linguistic Identities. Studies in Slavic Contact and Borderland Varieties, 177190. Wiesbaden: Harrassowitz Publ.

-, 2011a. "Language Contacts on the Russian-Chinese Border: The 'Second Birth' of Russian-Chinese Trade Pidgin”, in Tul'si Bhambry, Clare Griffin, Titus Hjelm \& Olga Voronina (eds), Perpetual motion? Transformation and Transition in Central, Eastern Europe and Russia, 72-84. London, UK: School of Slavonic and East European Studies, UC. http://discovery.ucl.ac.uk/1322705/

-, 2011b. "Transborder Trade on The Russian-Chinese Border: Problems of Interethnic Communication", in Bettina Bruns \& Judith Miggelbrink (eds), Subverting Borders. Doing Research on Smuggling and Small-Scale Trade, 107-128. Wiesbaden: Verlag für Sozialwissenschaften, Springer.

Fedorova, Kapitolina \& Tatiana Gavrilova, 2010. "Native Speakers of Russian in Interethnic Communication: Sociolinguistic Situations and Linguistic Strategies", in Arto Mustajoki, Ekaterina Protassova \& Nikolai Vakhtin (eds), Slavica Helsingiensia 40. Instrumentarium of Linguistics. Sociolinguistic Approaches to Non-Standard Russian, 52-67. Helsinki: Helsinki University Press.

Ferguson, Charles A., 1981. “'Foreigner Talk' as The Name of a Simplified Register”, International Journal of the Sociology of Language 28: 9-18. 
Ferguson, Charles A. \& Charles E. DeBose, 1977. "Simplified Registers, Broken Language, and Pidginization”, in Albert Valdman (ed.), Pidgin and Creole Linguistics, 99-125. London: Bloomington.

Friedrich, Paul, 1972. "Social Context and Semantic Feature: the Russian Pronominal Usage", in John Gumperz \& Dell Hymes (eds), Directions in Sociolinguistics: The Ethnography of Communication, 270-300. New York: Holt, Rinehart \& Winston.

Garrett, Peter, 2010. Attitudes to Language. Cambridge: Cambridge University Press.

Gelbras, Vilya, 2004. "Perspektivy kitajskoj migratsii na Dal'nem Vostoke" [Perspectives of the Chinese migrations in the Far East], Otechestvennye zapiski 4 (18). http://www.strana-oz. $\mathrm{ru} /$ ?numid $=19 \&$ article $=905$

Gudkov, Lev, 2007, "Pochemu my ne lyubim priezzhikh? [Why we do not like newcomers?]", Mir Rossii 16 (2): 48-83.

Halbwachs, Maurice, 1992. On Collective Memory. Chicago: University of Chicago Press.

Haskell, Robert E., 2009, "Unconscious Linguistic Referents to Race: Analysis and Methodological Frameworks", Discourse \& Society, 20: 9-84.

Hatch, Evelyn, 1983. "Simplified Input and Second Language Acquisition", in Roger W. Andersen (ed.), Pidginization and Creolization as Language Acquisition, 64-86. Rowley: Newbury House Pub.

Herman-Kinney, Nancy J. \& Larry T. Reynolds, 2003. Handbook of Symbolic Interactionism. New York: AltaMira.

Horsman, Mathew \& Andrew Marshall, 1994. After the Nation-State: Citizens, Tribalism and the New World Disorder. New York: Harper Collins Publishers.

Johnstone, Barbara, 2008. Discourse Analysis. Malden, M.A.: Blackwell.

Jorgensen, Marianne \& Louise Phillips, 2002. Discourse Analysis as Theory and Method. London; Thousand Oaks; New Delhi: Sage Publications.

Jupp, Thomas C., Celia Roberts \& Jenny Cook-Gumperz, 1982. "Language and Disadvantage: The Hidden Process", in John Gamperz (ed.), Language and Social Identity, 232-256. Cambridge: Cambridge University Press.

Krashen, Stephen D., 1981. Second Language Acquisition and Second Language Learning. Oxford: Pergamon.

Lakoff, George \& Mark Johnson, 1980. Metaphors we Live By. Chicago: The University of Chicago Press.

Larin, Viktor, 2001. "Poslantsy Podnebesnoj na Dal'nem Vostoke - legal'naye i nelegal'nye" [Celestial Empire's envoys in the Far East - legal and illegal ones], Diaspory 2-3: 76-112.

Lotman, Yurii, 1992. Izbrannye Statii [Selected Papers], Vol. 1. Tallinn: Aleksandra.

Maksimov, S., 1864. Na Vostoke. Poezdka na Amur (v 1860-1861 godakh). Dorozhnye zametki $i$ vospominaniya S. Maksimova [In the East. The Trip to the Amur (in 1860-1861). Traveller's Notes and Memoirs by S. Maksimov]. St. Petersburg.

Meisel, Jürgen M., 1977. "Linguistic Simplification: a Study of Immigrant Workers' Speech and foreigner talk", in Stephen P. Corder \& Eddy Roulet (eds), The Notion of Simplification, Interlanguages and Pidgins and their Relations to Second Language Pedagogy, 88-113. Neuchâtel: Université, Faculté des lettres; Genève: Droz.

Nickel, Gerhard, 1986. "Some Sociolinguistic Aspects of Error Analysis (EA) in Foreign Language (FL) Teaching", in Joshua Fishman (ed.), The Fergusonian Impact. In Honor of Charles A. Ferguson. Vol. 1, 455-470. Berlin; New York; Amsterdam: Mouton De Gruyter.

Oddo, John, 2011, “War Legitimation Discourse: Representing 'Us' and 'Them' in Four US Presidential Addresses", 2011, Discourse \& Society 22: 287-314.

O’Keefe, Anne, 2006. Investigating Media Discourse. London; New York: Routlege. 
Perekhvalskaia, Elena, 2007. "Dialektnye razlichiia kak rezultat iazykovogo sdviga (bikinskii dilaekt udegejskogo iazyka)" [Dialect Differences as a Result of Language Shift (Bikin Dialect of the Udege Language)], in Nikolai Vakhtin (ed.), Iazykovye izmeneniia v usloviiakh iazykovogo sdviga, 252-281. St. Petersburg: Nestor.

-, 2008. Russkie pidzhiny [Russian pidgins]. St. Petersburg: Aleteia.

Pickering, Sharon \& Leanne Weber, 2006. Borders, Mobility and Technologies of Control. Berlin: Springerverlag.

Portyakov, Vladimir, 2006. "Rossijskij vektor v global'noj kitajskoj migratsii”" [Russian vector in Chinese global migration], Problemy Dal'nego Vostoka, 2: 10-21.

Romaine, Suzanne, 1988. Pidgin and Creole Languages. London: Longman.

Scollon, Ronald \& Suzanne W. Scollon, 1995. Intercultural Communication. A Discourse Approach. Oxford, UK; Cambridge, USA: Blackwell.

Selinker, Larry, 1972. “Interlanguage”, International Review of Applied Linguistics, 10: 209-231.

Siegelbaum, Lewis H., 1978. “Another 'Yellow Peril': Chinese Migrants in the Russian Far East and the Russian reaction before 1917”, Modern Asian Studies 12 (2): 307-330.

Stern, Dieter, 2005. "Myths and Facts about the Kyakhta Trade Pidgin", Journal of Pidgin and Creole Languages 20 (1): 175-187.

Todd, Loreto, 1974. Pidgins and Creoles. London: Routledge.

Van Dijk, Teun A., 2002. "Discourse and Racism”, in David Goldberg \& John Solomos (eds), The Blackwell Companion to Racial and Ethnic Studies, 145-59. Oxford: Blackwell.

Voronkov, Viktor et al. (eds), 2002. Rasizm v yazyke sotsial'nykh nauk. [Racism in the Language of Social Sciences] St. Petersburg: Aleteya.

- (eds), 2008. Rasizm vyazyke obrazovaniya. [Racism in the Language of Education] St. Petersburg: Aleteya.

Wilson, Thomas M. \& Hastings Donnan, 1998. Border Identities. Nation and State at International Frontiers. Cambridge: Cambridge University Press.

Zhang, Xiaoling, 2002, “'Them' and 'Us' in Shanghai Today”, International Journal of the Sociology of Language 158: 141-161. 
